\title{
Simultaneous determination of standardized ileal digestible tryptophan and lysine for barrows from 15 to $30 \mathrm{~kg}$ live weight
}

\author{
T.J. Pasquetti ${ }^{\text {a,* }}$, P.C. Pozza ${ }^{\text {b }}$, I. Moreira ${ }^{\text {c }}$, T.C. Santos ${ }^{\text {b }}$, L.M. Diaz-Huepa ${ }^{\text {}}$, L.D. Castilha ${ }^{\text {, }}$, \\ D. Perondi ${ }^{\mathrm{d}}$, P.L.O. Carvalho ${ }^{\mathrm{e}}$, S.W. Kim ${ }^{\mathrm{f}}$ \\ a Departamento de Zootecnia, Universidade Estadual de Mato Grosso do Sul, Rodovia Aquidauana, Aquidauana, MS 79200-000, Brazil \\ ${ }^{\mathrm{b}}$ Departamento de Zootecnia, Universidade Estadual de Maringá, Avenida Colombo, 5790, Jd. Universitário, Maringá, PR, 87020-900, Brazil \\ ' Departamento de Zootecnia, Universidade Tecnológica Federal do Paraná, Estrada para Boa Esperança, Dois Vizinhos, PR 85660-000, Brazil \\ ${ }^{\mathrm{d}}$ Departamento de Zootecnia, Universidade Estadual Paulista, Via de Acesso Prof. Paulo Donato Castellane, Jaboticabal, SP 14884-900, Brazil \\ e Departamento de Zootecnia, Universidade Estadual do Oeste do Paraná, Rua Pernambuco, 1777, Marechal Cândido Rondon, PR 85960-000, Brazil \\ ${ }^{\mathrm{f}}$ Department of Animal Science, North Carolina State University, Raleigh, NC 27695, United States
}

\section{A R T I C L E I N F O}

\section{Article history:}

Received 27 November 2014

Received in revised form

19 September 2015

Accepted 22 September 2015

\section{Keywords:}

Lysine

Pigs

Response surface

Requirements

Standardized ileal amino acid digestibility

Tryptophan

\begin{abstract}
A B S T R A C T
The digestible amino acid (AA) determination of ingredients, or experimental diets, are essential in obtaining the real levels of AA that are being studied, as well as of other indispensable AA, because the lack of a single indispensable AA may limit pig growth performance. Two experiments were conducted to determine the optimum levels and the ideal ratio of standardized ileal digestible (SID) Trp and Lys for barrows from 15 to $30 \mathrm{~kg}$ of live weight. The first experiment (Exp. 1) was conducted to determine the SID AA content of the basal diet used in the growth performance study (Exp. 2). Ten crossbred barrows $(21.5 \pm 1.6 \mathrm{~kg}$ live weight) were used in Exp. 1. Pigs were fed a basal diet and a protein free diet to determine the SID of Trp, Lys, and all other indispensable AA of the basal diet. In Exp. 2, 64 barrows $(15.0 \pm 1.6 \mathrm{~kg})$ were allotted to 16 diets in a $4 \times 4$ factorial arrangement of treatments $(1.55,1.85,2.15$, and $2.45 \mathrm{~g}$ SID Trp and 9.72, 11.12, 12.52, and $13.92 \mathrm{~g}$ SID Lys $/ \mathrm{kg}$ ) with 4 replications per treatment. In both Exp. 1 and 2, each pig was considered as an experimental unit. Growth performance, Longissimus muscle (LM), backfat thickness, and plasma urea nitrogen (PUN) were evaluated. Average daily feed intake and average daily gain increased linearly $(P<0.05)$ with increasing levels of SID Trp. There was a quadratic effect $(P=0.04)$ of dietary SID Trp and Lys levels on the gain:feed, and the optimal levels were estimated to be $2.1(0.65 \mathrm{~g} /$ Mcal ME) and $11.98 \mathrm{~g} / \mathrm{kg}(3.71 \mathrm{~g} /$ Mcal ME), respectively, resulting in a SID Trp:Lys of 17.5:100. A quadratic effect of SID $\operatorname{Trp}(P=0.021)$ and Lys $(P=0.026)$ levels on LM was observed, and the optimum levels were 2.08 and $11.36 \mathrm{~g} / \mathrm{kg}$ diet, respectively, with a Trp:Lys of 18.3:100. The amount of PUN decreased linearly $(P=0.004)$ as SID Lys increased. For pigs used in our study (between 15 and $30 \mathrm{~kg}$ live weight), the SID Trp and SID Lys requirements are 2.10 and $11.98 \mathrm{~g} / \mathrm{kg}$, respectively. The corresponding Trp:Lys are 17.5:100.
\end{abstract}

(c) 2015 Elsevier B.V. All rights reserved.

\section{Introduction}

Most of the previous research evaluating amino acid (AA) requirements for pigs were designed to determine the requirement of $1 \mathrm{AA}$ at a time and did not consider metabolic interactions (antagonism and synergism) that may occur. Furthermore, few researchers have approached the simultaneous study of digestible Trp and Lys levels for pigs.

Tryptophan is the fourth limiting AA in practical diets, based on cereals, for pigs in growing phase (Jansman et al., 2007), while Lys

\footnotetext{
* Corresponding author. Fax: +55 6739042907.

E-mail address: pasquettizoo@yahoo.com.br (T.J. Pasquetti).
}

is the first. Because of its constancy in body protein and its metabolic destination, especially to lean tissue deposition, Lys is considered the most important nutrient for meat deposition in the bodies of growing pigs. Trptophan, however, also plays an essential role in protein synthesis, and as proposed by Jansman et al. (2007), its effect extends to feed intake regulation, being the precursor of serotonin (5-HT), which plays a central role in this process.

It is important to know the ratio between Lys and other AA before proceeding with feed formulation. The Trp:Lys reported by Baker and Chung (1992) was 18:100 for pigs from 10 to $20 \mathrm{~kg}$ of body weight. Recently Naatjes et al. (2014), using broken-line, curvelinear plateau and exponential models, for pigs from 15 to $35 \mathrm{~kg}$ of live weight, observed a better feed:gain for a diet based on wheat when the Trp:Lys was 17.0:100, 18.5:100, and 19.7:100, 
respectively. For a diet based on corn the better ratios were 19.9:100, 20.9:100, and 20.9:100, respectively.

Differences in digestible Trp:Lys are observed in many studies, especially because of mathematical models and response used (Naatjes et al., 2014), as well as environmental factors (Le Floc'h and Seve, 2007), sex and genetic potential of animals. Furthermore, most of the studies did not determine the ileal digestibility of AA contained in the ingredients or in the diet with the lowest level of digestible Trp and Lys.

The digestible AA determination of ingredients, or experimental diets, are essential in obtaining the real levels of AA that are being studied, as well as of other essential AA, as the lack of a single essential AA may limit pig performance. The current study was conducted to determine simultaneously the requirement for standardized ileal digestible (SID) Trp and Lys and the ratio between the $2 \mathrm{AA}$ for barrows between 15 and $30 \mathrm{~kg}$ live weight.

\section{Material and methods}

Two experiments were carried out in the Fazenda Experimental de Iguatemi at Universidade Estadual de Maringá/UEM and in the Nutrition Lab of the Animal Science Department. The experiments were approved by the UEM Animal Care and Use Committee (CEUA, Protocol no. 050/2011).

\subsection{Standardized ileal digestibility of amino acids of the basal diet} (Exp. 1)

\subsubsection{Animals, experimental design and diets}

This study was conducted to determine the digestible Trp and Lys contents of the basal diet and to establish whether other indispensable AA were limiting or not. Ten crossbred barrows (Landrace $\times$ Large White and Pietrain), averaging $21.5 \pm 1.57 \mathrm{~kg}$ of live weight, were individually allotted to metabolism cages, and distributed to a randomized block design. Treatments consisted of a basal diet, with the lowest levels of digestible $\operatorname{Trp}(1.5 \mathrm{~g} / \mathrm{kg}$ diet $)$ and Lys $(9.0 \mathrm{~g} / \mathrm{kg}$ diet) and a protein free diet (PFD) used to determine the endogenous losses of AA (Table 1).

The basal diet was formulated based on corn, soybean meal, soybean oil, AA, vitamins, minerals and additives, to meet the requirements proposed by Rostagno et al. (2011) for barrows from 15 to $30 \mathrm{~kg}$ of body weight, except for the crude protein, Trp, and Lys levels. In the PFD, rice hulls was used as fiber source. Chromic oxide $\left(\mathrm{Cr}_{2} \mathrm{O}_{3}\right)$ was used in the diets to determine the indigestibility factor. Diets were provided twice a day (at $0800 \mathrm{~h}$ and $1500 \mathrm{~h}$ ) and water was provided ad libitum. Feed was moistened and provided in amounts calculated based on metabolic size (BW0.75).

\subsubsection{Surgery procedure and digesta collection}

Animals were submitted to an adaptation period of $5 \mathrm{~d}$ to the experimental diets and cages. Sampling of ileal digesta was performed as proposed by Lazzeri (2011), which was adapted from Apolônio et al. (2002). Before proceeding with surgery, tranquilizers and an anesthetic were injected into the pigs. After depilation and disinfection of the surgical site in the abdominal cavity, laparotomy was preceded through a ventral incision in the cephalocaudal direction, of approximately $10 \mathrm{~cm}$. The segment of distal ileum was exteriorized, and the digesta flow between the ileocecal valve and the end of the ileocecal fold was closed with a hemostatic forceps. A segment of approximately $20 \mathrm{~cm}$ of the ileum has been cut and removed, washed with distilled water and dried with a paper towel. The ileal digesta from each treatment (basal diet and PFD) was collected and stored in plastic containers, and then the samples were lyophilized and composed by treatment for subsequent analysis. After collection procedure, pigs were euthanized.
Table 1

Composition of the basal diet and protein-free diet.

\begin{tabular}{|c|c|c|}
\hline Item & Basal diet & Protein-free diet \\
\hline \multicolumn{3}{|l|}{ Ingredient (g/kg) } \\
\hline Corn & 742.4 & - \\
\hline Soybean meal (45.2\% CP) & 136.8 & - \\
\hline Corn gluten meal $(60 \% \mathrm{CP})$ & 60.0 & - \\
\hline Dicalcium phosphate & 15.9 & 20.6 \\
\hline Limestone & 8.2 & 7.0 \\
\hline Soybean oil & 1.2 & - \\
\hline Vitamin-trace mineral premix ${ }^{\mathrm{b}}$ & 5.0 & 5.0 \\
\hline Sodium bicarbonate & 4.6 & - \\
\hline Sand & 1.5 & - \\
\hline Salt & 1.4 & 5.0 \\
\hline Glutamic acid & 7.7 & - \\
\hline L-Lys $\cong \mathrm{HCl}(78.4 \%)$ & 4.9 & - \\
\hline L-Thr (98.0\%) & 1.9 & - \\
\hline DL-Met $(99.0 \%)$ & 1.2 & - \\
\hline L-Trp $(98 \%)$ & 0.2 & - \\
\hline L-Val & 1.2 & - \\
\hline L-Ile & 0.5 & - \\
\hline Antioxidant $^{\mathrm{C}}$ & 0.1 & 0.1 \\
\hline Cromic oxide & 5.0 & 5.0 \\
\hline Starch & - & 727.0 \\
\hline Rice hulls & - & 30.0 \\
\hline Sugar & - & 200.0 \\
\hline Antibiotic $^{\mathrm{d}}$ & 0.05 & 0.00 \\
\hline \multicolumn{3}{|c|}{$\begin{array}{l}\text { Calculated composition ( } \mathrm{g} / \mathrm{kg} \text { unless indicated } \\
\text { otherwise) }\end{array}$} \\
\hline ME (kcal/kg) & 3,230 & 3,341 \\
\hline $\mathrm{CP}$ & 165.2 & 1.2 \\
\hline $\mathrm{Ca}$ & 7.7 & 7.7 \\
\hline Available P & 3.8 & 3.8 \\
\hline $\mathrm{Na}$ & 2.0 & 2.0 \\
\hline SID Lys & 9.00 & - \\
\hline SID Thr & 6.89 & - \\
\hline SID Met + Cys & 6.13 & - \\
\hline SID Trp & 1.50 & - \\
\hline SID Val & 7.55 & - \\
\hline SID Ile & 6.01 & - \\
\hline SID Leu & 16.13 & - \\
\hline SID Arg & 7.76 & - \\
\hline
\end{tabular}

a $\mathrm{SID}=$ standardized ileal digestible, $\mathrm{ME}=$ metabolizable energy; and $\mathrm{CP}=$ crude protein

b Provided per kilogram of diet: vitamin A,10,000 IU; vitamin D3, $2000 \mathrm{IU}$; vitamin E, $40 \mathrm{IU}$; vitamin K3, $3.12 \mathrm{mg}$; vitamin B1, $1.57 \mathrm{mg}$; vitamin B2, $4.0 \mathrm{mg}$; vitamin B6, $2.18 \mathrm{mg}$; vitamin B12, $23 \mu \mathrm{g}$; calcium pantothenate, $15.2 \mathrm{mg}$; niacin, $30.38 \mathrm{mg}$; folic acid, $0.3 \mathrm{mg}$; biotin, $0.12 \mathrm{mg}$; choline, $360 \mathrm{mg} ; \mathrm{Zn}, 125 \mathrm{mg}$; Fe, $81 \mathrm{mg}$; Cu, $12 \mathrm{mg}$; Mn, $40.3 \mathrm{mg} ; \mathrm{I}, 1.12 \mathrm{mg}$; Se, $0.32 \mathrm{mg}$; Co, $0.2 \mathrm{mg}$; and antioxidant, $5 \mathrm{mg}$.

${ }^{c}$ Antioxidant $=$ butylated hydroxytoluene.

d Antibiotic: Leucomag (Ceva Animal Health, Paulínia, Brazil).

\subsubsection{Chemical analysis}

Dry matter and chromic oxide were measured in the basal diet and PFD, as previously described by the AOAC (2012) and Kimura and Miller (1957), respectively. The AA composition of diets, in the digesta and rice hulls, was analyzed using ninhydrin for postcolumn derivatization and norleucine as the internal standard. Performic acid was used to oxidize the AA, which was neutralized with sodium metabisulfite (Llames and Fontaine, 1994; Commission Directive, 1998), and then hydrolyzed (AOAC, 2012). Amino acid quantification was performed as proposed by Rosenfelder et al. (2015). Tryptophan was determined by fluorescence detection using high performance liquid chromatography (Commission Directive, 2000).

\subsection{Standardized ileal digestible Trp and Lys levels for crossbred barrows from 15 to $30 \mathrm{~kg}$ live weight (Exp. 2)}

\subsubsection{Animals, experimental design and diets}

Sixty-four individually housed crossbred barrows (Tybor $\times$ Topigs $20 ; 15.00 \pm 1.63 \mathrm{~kg}$ ) were allotted to 16 treatments in 
Table 2

Composition of experimental diets. ${ }^{a}$

\begin{tabular}{|c|c|c|c|c|c|c|c|c|c|c|c|c|c|c|c|c|}
\hline \multirow{2}{*}{$\begin{array}{l}\text { SID Trp }(\mathrm{g} / \mathrm{kg}): \\
\text { SID Lys }(\mathrm{g} / \mathrm{kg}) \text { : }\end{array}$} & \multicolumn{4}{|l|}{1.55} & \multicolumn{4}{|l|}{1.85} & \multicolumn{4}{|l|}{2.15} & \multicolumn{4}{|l|}{2.45} \\
\hline & 9.72 & 11.12 & 12.52 & 13.92 & 9.72 & 11.12 & 12.52 & 13.92 & 9.72 & 11.12 & 12.52 & 13.92 & 9.72 & 11.12 & 12.52 & 13.92 \\
\hline \multicolumn{17}{|l|}{ Ingredient (g/kg) } \\
\hline Corn & 742.4 & 742.4 & 742.4 & 742.4 & 742.4 & 742.4 & 742.4 & 742.4 & 742.4 & 742.4 & 742.4 & 742.4 & 742.4 & 742.4 & 742.4 & 742.4 \\
\hline Soybean meal & 136.8 & 136.8 & 136.8 & 136.8 & 136.8 & 136.8 & 136.8 & 136.8 & 136.8 & 136.8 & 136.8 & 136.8 & 136.8 & 136.8 & 136.8 & 136.8 \\
\hline Corn gluten meal $(60 \% \mathrm{CP})$ & 60.0 & 60.0 & 60.0 & 60.0 & 60.0 & 60.0 & 60.0 & 60.0 & 60.0 & 60.0 & 60.0 & 60.0 & 60.0 & 60.0 & 60.0 & 60.0 \\
\hline Dicalcium phosphate & 15.9 & 15.9 & 15.9 & 15.9 & 15.9 & 15.9 & 15.9 & 15.9 & 15.9 & 15.9 & 15.9 & 15.9 & 15.9 & 15.9 & 15.9 & 15.9 \\
\hline Limestone & 8.2 & 8.2 & 8.2 & 8.2 & 8.2 & 8.2 & 8.2 & 8.2 & 8.2 & 8.2 & 8.2 & 8.2 & 8.2 & 8.2 & 8.2 & 8.2 \\
\hline Soybean oil & 1.2 & 1.2 & 1.2 & 1.2 & 1.2 & 1.2 & 1.2 & 1.2 & 1.2 & 1.2 & 1.2 & 1.2 & 1.2 & 1.2 & 1.2 & 1.2 \\
\hline Vitamin-trace mineral premix ${ }^{\mathrm{b}}$ & 5.0 & 5.0 & 5.0 & 5.0 & 5.0 & 5.0 & 5.0 & 5.0 & 5.0 & 5.0 & 5.0 & 5.0 & 5.0 & 5.0 & 5.0 & 5.0 \\
\hline Sodium bicarbonate & 4.64 & 5.49 & 6.35 & 7.18 & 4.64 & 5.49 & 6.34 & 7.18 & 4.64 & 5.49 & 6.34 & 7.18 & 4.64 & 5.49 & 6.34 & 7.18 \\
\hline Sand & 6.50 & 7.14 & 7.79 & 7.55 & 6.64 & 7.30 & 7.95 & 7.24 & 6.80 & 7.45 & 8.11 & 6.94 & 6.92 & 7.58 & 8.24 & 6.69 \\
\hline Salt & 1.42 & 0.84 & 0.26 & 0.00 & 1.42 & 0.84 & 0.26 & 0.00 & 1.42 & 0.84 & 0.26 & 0.00 & 1.42 & 0.83 & 0.25 & 0.00 \\
\hline Glutamic acid & 7.66 & 4.91 & 2.16 & 0.00 & 7.19 & 4.44 & 1.69 & 0.00 & 6.73 & 3.98 & 1.23 & 0.00 & 6.35 & 3.60 & 8.50 & 0.00 \\
\hline L-Lys $\cong \mathrm{HCl}(78.4 \%)$ & 4.91 & 6.73 & 8.55 & 10.37 & 4.91 & 6.73 & 8.55 & 10.37 & 4.91 & 6.73 & 8.55 & 10.37 & 4.91 & 6.73 & 8.55 & 10.37 \\
\hline L-Thr $(98.0 \%)$ & 1.96 & 1.96 & 1.96 & 1.96 & 1.96 & 1.96 & 1.96 & 1.96 & 1.96 & 1.96 & 1.96 & 1.96 & 1.96 & 1.96 & 1.96 & 1.96 \\
\hline DL-Met (99.0\%) & 1.26 & 1.26 & 1.26 & 1.26 & 1.26 & 1.26 & 1.26 & 1.26 & 1.26 & 1.26 & 1.26 & 1.26 & 1.26 & 1.26 & 1.26 & 1.26 \\
\hline L-Trp (98\%) & 0.25 & 0.25 & 0.25 & 0.25 & 0.56 & 0.56 & 0.56 & 0.56 & 0.87 & 0.87 & 0.87 & 0.87 & 1.12 & 1.12 & 1.12 & 1.12 \\
\hline L-Val & 1.19 & 1.19 & 1.19 & 1.19 & 1.19 & 1.19 & 1.19 & 1.19 & 1.19 & 1.19 & 1.19 & 1.19 & 1.19 & 1.19 & 1.19 & 1.19 \\
\hline L-Ile & 0.5 & 0.5 & 0.5 & 0.5 & 0.5 & 0.5 & 0.5 & 0.5 & 0.5 & 0.5 & 0.5 & 0.5 & 0.5 & 0.5 & 0.5 & 0.5 \\
\hline Antioxidant $^{\mathrm{C}}$ & 0.1 & 0.1 & 0.1 & 0.1 & 0.1 & 0.1 & 0.1 & 0.1 & 0.1 & 0.1 & 0.1 & 0.1 & 0.1 & 0.1 & 0.1 & 0.1 \\
\hline Antibiotic $^{\mathrm{d}}$ & 0.05 & 0.05 & 0.05 & 0.05 & 0.05 & 0.05 & 0.05 & 0.05 & 0.05 & 0.05 & 0.05 & 0.05 & 0.05 & 0.05 & 0.05 & 0.05 \\
\hline \multicolumn{17}{|c|}{ Calculated composition ( $\mathrm{g} / \mathrm{kg}$ unless indicated otherwise) } \\
\hline $\mathrm{ME}(\mathrm{kcal} / \mathrm{kg})$ & 3,230 & 3,230 & 3,230 & 3,230 & 3,230 & 3,230 & 3,230 & 3,230 & 3,230 & 3,230 & 3,230 & 3,230 & 3,230 & 3,230 & 3,230 & 3,230 \\
\hline $\mathrm{CP}$ & 165.2 & 165.2 & 165.2 & 165.2 & 165.2 & 165.2 & 165.2 & 165.2 & 165.2 & 165.2 & 165.2 & 165.2 & 165.2 & 165.2 & 165.2 & 165.2 \\
\hline $\mathrm{Ca}$ & 7.7 & 7.7 & 7.7 & 7.7 & 7.7 & 7.7 & 7.7 & 7.7 & 7.7 & 7.7 & 7.7 & 7.7 & 7.7 & 7.7 & 7.7 & 7.7 \\
\hline Available P & 3.8 & 3.8 & 3.8 & 3.8 & 3.8 & 3.8 & 3.8 & 3.8 & 3.8 & 3.8 & 3.8 & 3.8 & 3.8 & 3.8 & 3.8 & 3.8 \\
\hline $\mathrm{Na}$ & 2.0 & 2.0 & 2.0 & 2.0 & 2.0 & 2.0 & 2.0 & 2.0 & 2.0 & 2.0 & 2.0 & 2.0 & 2.0 & 2.0 & 2.0 & 2.0 \\
\hline Crude fiber & 20.8 & 20.8 & 20.8 & 20.8 & 20.8 & 20.8 & 20.8 & 20.8 & 20.8 & 20.8 & 20.8 & 20.8 & 20.8 & 20.8 & 20.8 & 20.8 \\
\hline SID Lys & 9.72 & 11.12 & 12.52 & 13.92 & 9.72 & 11.12 & 12.52 & 13.92 & 9.72 & 11.12 & 12.52 & 13.92 & 9.72 & 11.12 & 12.52 & 13.92 \\
\hline SID Thr & 7.26 & 7.26 & 7.26 & 7.26 & 7.26 & 7.26 & 7.26 & 7.26 & 7.26 & 7.26 & 7.26 & 7.26 & 7.26 & 7.26 & 7.26 & 7.26 \\
\hline SID Met + Cys & 6.46 & 6.46 & 6.46 & 6.46 & 6.46 & 6.46 & 6.46 & 6.46 & 6.46 & 6.46 & 6.46 & 6.46 & 6.46 & 6.46 & 6.46 & 6.46 \\
\hline SID Trp & 1.55 & 1.55 & 1.55 & 1.55 & 1.85 & 1.85 & 1.85 & 1.85 & 2.15 & 2.15 & 2.15 & 2.15 & 2.45 & 2.45 & 2.45 & 2.45 \\
\hline SID Val & 8.51 & 8.51 & 8.51 & 8.51 & 8.51 & 8.51 & 8.51 & 8.51 & 8.51 & 8.51 & 8.51 & 8.51 & 8.51 & 8.51 & 8.51 & 8.51 \\
\hline SID Ile & 6.74 & 6.74 & 6.74 & 6.74 & 6.74 & 6.74 & 6.74 & 6.74 & 6.74 & 6.74 & 6.74 & 6.74 & 6.74 & 6.74 & 6.74 & 6.74 \\
\hline SID Leu & 17.47 & 17.47 & 17.47 & 17.47 & 17.47 & 17.47 & 17.47 & 17.47 & 17.47 & 17.47 & 17.47 & 17.47 & 17.47 & 17.47 & 17.47 & 17.47 \\
\hline SID Arg & 8.37 & 8.37 & 8.37 & 8.37 & 8.37 & 8.37 & 8.37 & 8.37 & 8.37 & 8.37 & 8.37 & 8.37 & 8.37 & 8.37 & 8.37 & 8.37 \\
\hline $\mathrm{DEB}(\mathrm{mEq} / \mathrm{kg})$ & 142.5 & 142.5 & 142.5 & 142.5 & 142.5 & 142.5 & 142.5 & 142.5 & 142.5 & 142.5 & 142.5 & 142.5 & 142.5 & 142.5 & 142.5 & 142.5 \\
\hline
\end{tabular}

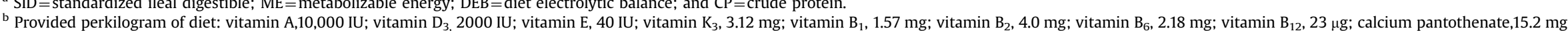
niacin, 30.38 mg; folic acid, 0.3 mg; biotin, $0.12 \mathrm{mg}$; choline, 360 mg; Zn, 125 mg; Fe, 81 mg; Cu, 12 mg; Mn, 40.3 mg ; I, 1.12 mg; Se, 0.32 mg; Co, 0.2 mg; andantioxidant, 5 mg.

'Antioxidant: butylatedhydroxytoluene.

d Antibiotic: Leucomag (Ceva Animal Health, Paulínia, Brazil). 
a completely randomized block design with 4 replications per treatment. Treatments were arranged as a $4 \times 4$ factorial ( 4 levels of SID Trp, 1.55, 1.85, 2.15, and $2.45 \mathrm{~g} / \mathrm{kg}$ and 4 levels of SID Lys, $9.72,11.12,12.52$, and $13.92 \mathrm{~g} / \mathrm{kg}$ diet). The lowest $\operatorname{Trp}(1.55)$ and Lys (9.72) levels were previously determined in the digestibility assay (Exp. 1), using a basal diet and a PFD.

The crude protein content of the basal diet $(165.2 \mathrm{~g} / \mathrm{kg}$ diet $)$ was reduced compared to the value proposed by Rostagno et al. (2011), which was $192.4 \mathrm{~g} / \mathrm{kg}$ diet. The experimental diets were prepared by adding Trp and Lys at the expense of sand to the basal diet (Table 2). Glutamic acid was used to maintain the same N levels in all diets.

At the end of the study, body weight (BW) and feed intake were recorded and average daily gain (ADG), average daily feed intake (ADFI) and gain:feed (G:F) were calculated. Ultrasound measurements was performed using an ultrasound instrument (Aloka SSD 500; Aloka, Campinas, SP, Brazil). Previously, the P2 position, 6$7 \mathrm{~cm}$ away from the midline, had been determined, shaved and the images captured. The measurements of backfat thickness (BF) and Longissimus muscle (LM) were performed using a software (ImageJ; National Institute of Health, Bathesda, MD, United States).

\subsubsection{Blood sample collection and processing}

At the end of the study, after $6 \mathrm{~h}$ fasting, blood sampling was performed from the jugular vein $(6 \mathrm{~mL})$ and samples were transferred into glass tubes containing heparin (Cai et al., 1994) to analyze plasma urea nitrogen (PUN). Plasmatic urea was multiplied by 0.467 , which represents the amount of $\mathrm{N}$ in the urea molecule (Newman and Price, 1999). After sampling, blood was centrifuged at $3000 \times \mathrm{g}$ for $15 \mathrm{~min}$ at room temperature to obtain the plasma, which was placed in propylene microtubes. Commercial kits (Gold Analisa Diagnostica Ltda., Belo Horizonte, MG, Brazil) were used to determine PUN, which was measured by spectrophotometer (BIOPLUS 2000; Bioplus, Barueri, SP, Brazil).

\subsubsection{Statistical analysis}

For all variables, initial weight was used as covariable and the model included dietary treatments and block. Each pig was considered as an experimental unit. The statistical analysis were performed using the Sistema de Análises Estatísticas e Genéticas SAEG (Universidade Federal de Viçosa, Viçosa, MG, Brazil). All variables were analyzed using response surface methodology. Additionally, when the response surface models were not fitted, orthogonal polynomial contrast coefficients were used to determine linear and quadratic effects of increasing levels of SID Trp and Lys.

\section{Results}

\subsection{Ileal digestibility of amino acids of the basal diet (Exp. 1)}

The results for endogenous AA losses and AA digestibility for the basal diet are presented in Table 3. The greatest endogenous losses were for Glu, Gly, Thr, Asp, and Pro. The lowest endogenous losses were for Met and Trp. Methionine, Leu, Thr, and Phe showed the largest coefficients of SID (CSID), which were 96.79, 96.00, 95.58, and $95.40 \%$, respectively. A smaller CSID was noted for Pro (73.94\%).

\subsection{Digestible Trp and Lys levels for crossbred barrows, from 15 to} $30 \mathrm{~kg}$ live weight (Exp. 2)

\subsubsection{Performance, back fat thickness, Longissimus muscle and} plasma urea nitrogen

All performance, BF, LM and PUN results are presented in Table 4 . There was no interaction between digestible Trp and Lys for
Table 3

Ileal endogenous amino acids (EAA; $\mathrm{mg} / \mathrm{g}$ ), apparent ileal digestible (AID) and standardized ileal digestible (SID) AA contents, and the determined SID (SIDDet) and calculated SID (SIDCal) AA contents of the basal diet.

\begin{tabular}{llllll}
\hline AA & EAA $(\mathrm{mg} / \mathrm{g})$ & AID $(\%)$ & SID $(\%)$ & SIDDet $(\mathrm{g} / \mathrm{kg})$ & SIDCal $(\mathrm{g} / \mathrm{kg})$ \\
\hline Met & 0.038 & 93.39 & 96.79 & 3.97 & 3.75 \\
Cys & 0.070 & 77.04 & 86.02 & 2.49 & 2.38 \\
Met + Cys & 0.108 & 86.86 & 92.58 & 6.46 & 6.13 \\
Lys & 0.125 & 89.91 & 94.38 & 9.72 & 9.01 \\
Thr & 0.258 & 83.11 & 95.58 & 7.26 & 6.89 \\
Trp & 0.056 & 79.44 & 91.27 & 1.55 & 1.50 \\
Arg & 0.127 & 88.75 & 94.00 & 8.37 & 7.76 \\
Ile & 0.106 & 89.46 & 94.96 & 6.74 & 6.01 \\
Leu & 0.200 & 91.96 & 96.00 & 17.47 & 16.13 \\
Val & 0.163 & 87.82 & 94.54 & 8.51 & 7.55 \\
His & 0.061 & 87.47 & 92.74 & 3.99 & - \\
Phe & 0.112 & 90.58 & 95.40 & 8.11 & - \\
Gly & 0.372 & 70.12 & 92.12 & 5.71 & - \\
Ser & 0.208 & 84.15 & 93.86 & 7.41 & - \\
Pro & 0.248 & 66.66 & 73.94 & 0.24 & - \\
Ala & 0.179 & 88.27 & 94.63 & 9.84 & - \\
Asp & 0.276 & 83.91 & 91.29 & 12.60 & - \\
Glu & 0.303 & 91.24 & 94.23 & 35.24 & - \\
\hline
\end{tabular}

${ }^{a}$ EAA were determined using a protein-free dietand based on per gram of protein-free diet consumed.

the performance, BF, LM and PUN. Using response surface analysis, ADFI increased linearly according to the SID Trp levels, and for Lys a quadratic effect was noted $\left(4.99837+0.133194^{*}\right.$ Trp $0.679048^{*}$ Lys $+0.028402^{*}$ Lys $2, R^{2}=0.90$ ). For PUN and average daily gain (ADG), polynomial regression model showed a better fit, in which PUN reduced linearly (14.9613-0.602950* Lys, $R^{2}=0.99$ ) with increasing levels of digestible Lys and ADG increased linearly $\left(0.49769+0.08903^{*} \operatorname{Trp}, R^{2}=0.72\right)$ according to the SID Trp levels.

No differences were observed on BF. Using a response surface analysis, the maximum response for $\mathrm{G}: \mathrm{F}(P=0.042)$ occurred at $2.10 \mathrm{~g} / \mathrm{kg}$ diet $(0.210 \%)$ of $\operatorname{Trp}$ and $11.98 \mathrm{~g} / \mathrm{kg}$ diet $(1.198 \%)$ of Lys, providing a Trp:Lys of 17.5:100 (Fig. 1), while the maximum response for LM occurred at $2.08 \mathrm{~g} / \mathrm{kg}$ diet $(0.208 \%)$ of Trp and the minimum response of LM occurred at $11.36 \mathrm{~g} / \mathrm{kg}$ diet $(1.136 \%)$ of Lys, providing a Trp:Lys of 18.3:100 (Fig. 2).

\section{Discussion}

\subsection{Ileal digestibility of the basal diet amino acids (Exp. 1)}

The greatest endogenous losses of Gly, Glu and Asp found in our study are in line with Yin et al. (2008). Most of the endogenous protein is hydrolyzed and reabsorbed before reaching the distal ileum (Yin et al., 2008.), and most of the remaining excreted protein is derived from deconjugated bile salts and mucin glycoproteins (Moughan and Schuttert, 1991; Stein et al., 2001), which, according to Yin et al. (2008), are rich in Gly (mostly bile) and Pro, Glu, Asp and Thr (mainly of mucin glycoproteins), corroborating the results obtained in our study.

Our EIAA values for Arg, Lys, Met, Thr and Phe are similar to those observed by Pozza et al. (2003). The differences observed between our values and those in the literature for the coefficients of SIDAA, as well as the different ileal endogenous losses, support the hypothesis that the determination of digestible AA in the ingredients or in the basal diet $A A$, to be used in the requirement determination of $\mathrm{AA}$, provides greater accuracy in estimating the optimal level, and it also will depend on the ingredients used in feed formulation, the live weight of the pigs and feed intake.

The determined SID (SIDDet) of the BD were higher than calculated SID (SIDcalc), which means that SID levels of all AA were above requirements, and the addition of industrial AA in the diets 
Table 4

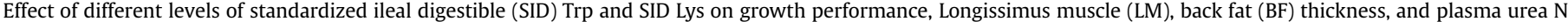
(PUN) in grower pigs. ${ }^{a}$

\begin{tabular}{|c|c|c|c|c|c|c|c|c|}
\hline \multicolumn{2}{|c|}{ SID amino acid (g/kg) } & \multirow[t]{2}{*}{ IBW (kg) } & \multirow[t]{2}{*}{$\mathrm{ADG}(\mathrm{kg})$} & \multirow[t]{2}{*}{ ADFI (kg) } & \multirow[t]{2}{*}{$\mathrm{G}: \mathrm{F}(\mathrm{kg} / \mathrm{kg})$} & \multirow[t]{2}{*}{$\mathrm{BF}(\mathrm{mm})$} & \multirow[t]{2}{*}{$\mathrm{LM}(\mathrm{mm})$} & \multirow[t]{2}{*}{ PUN (mg/dL) } \\
\hline Trp & Lys & & & & & & & \\
\hline \multirow[t]{4}{*}{1.55} & 9.72 & 15.02 & 0.697 & 1.33 & 0.522 & 4.90 & 24.66 & 8.98 \\
\hline & 11.12 & 15.09 & 0.647 & 1.18 & 0.545 & 4.94 & 23.97 & 7.64 \\
\hline & 12.52 & 15.11 & 0.553 & 1.09 & 0.499 & 4.63 & 21.04 & 8.81 \\
\hline & 13.92 & 15.00 & 0.547 & 1.14 & 0.470 & 3.86 & 24.56 & 7.45 \\
\hline \multirow{4}{*}{1.85} & 9.72 & 14.98 & 0.682 & 1.34 & 0.510 & 5.37 & 24.50 & 8.47 \\
\hline & 11.12 & 14.97 & 0.647 & 1.21 & 0.535 & 4.68 & 24.34 & 9.54 \\
\hline & 12.52 & 14.93 & 0.697 & 1.24 & 0.557 & 5.01 & 22.58 & 7.55 \\
\hline & 13.92 & 15.19 & 0.718 & 1.35 & 0.531 & 5.14 & 25.25 & 5.27 \\
\hline \multirow[t]{4}{*}{2.15} & 9.72 & 15.03 & 0.702 & 1.40 & 0.502 & 5.82 & 24.74 & 9.47 \\
\hline & 11.12 & 15.03 & 0.668 & 1.22 & 0.549 & 4.90 & 24.72 & 7.40 \\
\hline & 12.52 & 15.17 & 0.680 & 1.20 & 0.568 & 4.39 & 24.28 & 6.59 \\
\hline & 13.92 & 14.94 & 0.755 & 1.39 & 0.543 & 5.20 & 25.66 & 6.64 \\
\hline \multirow[t]{4}{*}{2.45} & 9.72 & 14.91 & 0.679 & 1.32 & 0.514 & 5.05 & 23.42 & 9.94 \\
\hline & 11.12 & 14.81 & 0.652 & 1.27 & 0.509 & 5.08 & 23.25 & 8.10 \\
\hline & 12.52 & 14.93 & 0.722 & 1.34 & 0.539 & 5.17 & 24.13 & 6.53 \\
\hline & 13.92 & 14.92 & 0.747 & 1.37 & 0.545 & 5.14 & 25.12 & 7.31 \\
\hline Pooled SEM & & 0.20 & 0.020 & 0.03 & 0.020 & 0.11 & 0.29 & 0.31 \\
\hline \multicolumn{9}{|l|}{$P$-value } \\
\hline \multicolumn{9}{|l|}{ SID Trp } \\
\hline Linear & & - & 0.006 & 0.014 & 0.100 & 0.087 & 0.086 & 0.740 \\
\hline Quadratic & & - & 0.086 & 0.330 & 0.042 & 0.290 & 0.021 & 0.440 \\
\hline \multicolumn{9}{|l|}{ SID Lys } \\
\hline Linear & & - & 0.880 & 0.496 & 0.599 & 0.120 & 0.109 & 0.004 \\
\hline Quadratic & & - & 0.140 & 0.004 & 0.042 & 0.310 & 0.026 & 0.788 \\
\hline Interaction & & - & 0.200 & 0.410 & 0.056 & 0.470 & 0.660 & 0.730 \\
\hline
\end{tabular}

${ }^{\mathrm{a}} \mathrm{IBW}=$ initial body weight;ADG = average daily gain;ADFI = average daily feed intake; and G:F= gain:feed.

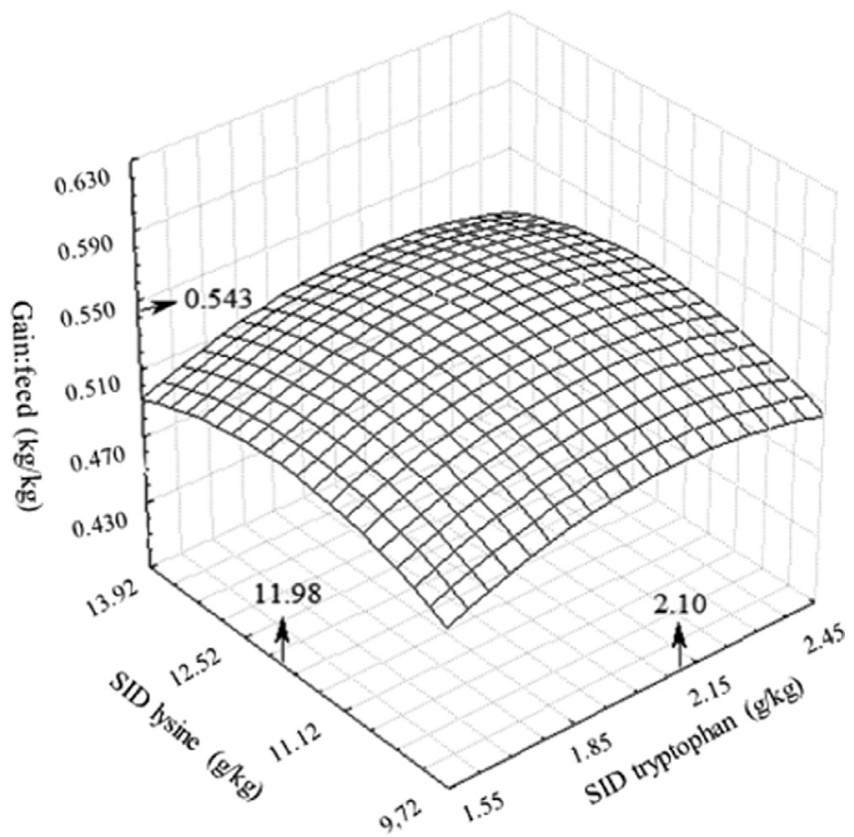

Fig. 1. The response surface for gain:feed for crossbred barrows (15-30 kg) offered diets with different levels of standardized ileal digestible (SID) Trp (X) and SID Lys (Z). Gain:feed $=-0.6779+0.4419^{*} X-0.1053^{*} X^{2}+0.1262^{*} Z-0.005261^{*} Z^{2} ; R^{2}=0.76$; Residual standard deviation $=0,04$; and $P=0.04$.

formulated for the performance study was not necessary.

4.2. Digestible Trp and Lys levels for crossbred barrows, from 15 to $30 \mathrm{~kg}$ of body Weight (Exp. 2)

4.2.1. Performance, back fat thickness, Longissimus muscle and plasma urea nitrogen

The Trp elicited increase in ADFI in our study may be related to

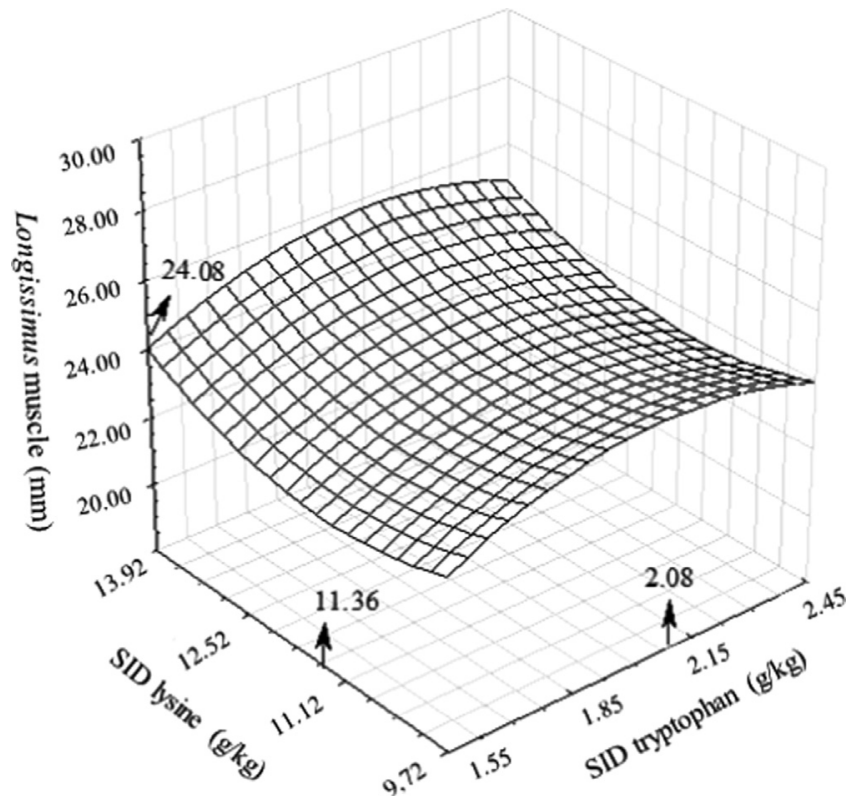

Fig. 2. The response surface for Longissimus muscle (LM) for crossbred barrows (15$0 \mathrm{~kg}$ ) offered diets with different levels of standardized ileal digestible (SID) tryptophan $(\mathrm{X})$ and SID lysine $(\mathrm{Z}) . \mathrm{LM}=30.5037+24.9730 * \mathrm{X}-5.9960 * \mathrm{X}^{2}-5.7100 * \mathrm{Z}+0.2512 * \mathrm{Z}^{2} ; R^{2}$ : 0.49 ; residual standard deviation $=2,19$; and $P=0.02$.

the greatest Trp availability in the brain, which may have increased 5-HT production, stimulating feed intake (Henry et al., 1992). Zhang et al. (2007) noted increase in the feed intake and ADG of pigs after weaning, according to increasing levels of Trp in the diets, and emphasized that ghrelin levels in the gastric fundus and duodenum increased with the addition of Trp, concluding that ghrelin may be a gut hormone responsive to Trp, which can regulate the feed intake to meet the animal's requirements. On the 
other hand, others studies showed that there was no effect of Trp levels on ADFI, ADG and F:G (Haese et al., 2006; Liu et al., 2013).

We found the lesser ADFI at the level of 1.195\% of SID Lys [corresponding to $3.70 \mathrm{~g}$ of SID/Mcal of metabolizable energy (ME) - and $11.11 \mathrm{~g} /$ day], which is similar to the requirement proposed by the National Research Council (NRC 2012), which is 1.23\% of SID Lys corresponding to $11.1 \mathrm{~g} /$ day and $3.66 \mathrm{~g}$ of SID Lys/Mcal of ME. The value observed for ADFI is similar to that obtained for G:F in our study, in which the better G:F was observed at levels of $0.210 \%$ of the diet $(0.65 \mathrm{~g} /$ Mcal ME) and $1.198 \%$ of the diet $(3.71 \mathrm{~g} /$ Mcal of $\mathrm{ME}$ ), for SID Trp and Lys, respectively, providing a SID Trp:Lys of 17.5:100. A lower Trp:Lys (16.2:100) was proposed by the NRC (2012) for pigs from 11 to $25 \mathrm{~kg}$.

Similar results were found in Susenbeth (2006) meta-analysis, wherein 33 studies were evaluated in which the BW of animals ranged from 4.6 to $115 \mathrm{~kg}$. The author concluded that a digestible Trp:Lys of 17.0:100 may be suggested and emphasized that the optimum ratio tends to be lower when it is expressed in terms of ileal digestible AA. However, in another meta-analysis study, in which data from 41 experiments were used, based on F:G, a Trp: Lys of 20.3:100 was suggested, for pigs from 7 to $25 \mathrm{~kg}$ of BW (Simongiovanni et al., 2009), which is similar to the ratio proposed by Zhang et al. (2012), using pigs from 25 to $50 \mathrm{~kg}$ of body weight (based on F:G and using a linear-break point model).

The optimum levels of SID Trp (0.210\%) and SID Lys (1.198\%) observed for the G:F corresponds to 2.56 and $14.6 \mathrm{~g}$ per day or 0.65 and $3.71 \mathrm{~g}$ per Mcal of ME, respectively. Using broken-line analysis, Quant et al. (2012) obtained a Trp:Lys ratio of 15.7:100 for ADG and 15.8:100 for PUN, using pigs from 20 to $50 \mathrm{~kg}$ of body weight.

The requirements proposed by Rostagno et al. (2011), for crossbred barrows with top performance, from 15 to $30 \mathrm{~kg}$, are $0.197 \%$ and $1.093 \%$ for SID Trp and SID Lys, which corresponds to $2.49 \mathrm{~g} /$ day and $13.82 \mathrm{~g} /$ day or 0.61 and $3.38 \mathrm{~g} /$ Mcal of ME, respectively, resulting in a digestible Trp:Lys ratio of 18:100. The Lys (1.23\%) and $\operatorname{Trp}(0.200 \%)$ values proposed by the NRC (2012) correspond to $1.8 \mathrm{~g} /$ day and 0.59 and $3.66 \mathrm{Mcal} / \mathrm{kg}$ of ME, respectively.

Using different levels of SID Lys for pigs from 11 to $27 \mathrm{~kg}$, Kendall et al. (2008) reported that $1.30 \%$ Lys (3.81 g of Lys/Mcal of $\mathrm{ME}$ ) was necessary to maximize performance (ADG and $F: G$ ). However, the authors only increased the digestible levels of Lys in the diets, holding constant the digestible Trp (0.23\%) level. When calculated the Trp:Lys ratio in the diet, in which the percentage of digestible Lys (1.32\%) is close to the breakpoint (1.30\%), a ratio of 17.4:100 was calculated, which is similar to that obtained in our study (17.5:100).

Working with different levels of SID Lys $(1.22,1.32,1.42,1.52$, $1.62 \%$ ) for pigs from 7 to $14 \mathrm{~kg}$, Nemechek et al. (2012) obtained the best results for weight gain and $F: G$ at levels of $1.34 \%$ and $1.46 \%$, respectively. Although the study was carried out only to determine the Lys level, when determining the Trp:Lys ratio in diets that promoted better performance a Trp:Lys ratio of 18.2:100 and 16.9:100 was calculated for weight gain and $F: G$, respectively. Similarly, Nørgaard et al. (2015) by fitting a curvelinear -plateau model, based on ADFI, ADG and G:F, estimated a SID Trp:Lys ratio of 20:100, 20:100 and 16:100 respectively, and when fitting a broken-line model a SID Trp:Lys ratio of 18:100, 18:100 and 15:100 were estimated, respectively, for pigs from 7 to $14 \mathrm{~kg}$.

Based on performance and nitrogen balance, Zangeronimo (2006) concluded that a digestible Lys level of $1.05 \%$ should be recommended for pigs from 9 to $20 \mathrm{~kg}$ of body weight, in diets containing $16 \%$ and $18 \%$ of crude protein. With similar dietary levels of crude protein (16.52\%), and with heavier pigs, our results have shown that the SID Lys requirement is higher $(1.198 \%$ and $1.136 \%$ for G:F and LM, respectively).

The Trp:Lys ratio obtained here is similar to that reported in others studies. However, when the requirements for the $2 \mathrm{AA}$ are expressed as g/day or in relation to $\mathrm{ME}$, the values are generally greatest than those found in tables of nutrient requirements (NRC, 2012; Rostagno et al., 2011). This can be attributed to the ability of the animals used in these studies to express their genetic potential, since this will result in different requirements of nutrients. Additionally, the determination of nutritional requirements can be influenced by the statistical methods used, by the environment in which the research was conducted, the number of animals per experimental unit, basic types of cereals used in animal feed, production stage, sex and physiological state, among other factors.

It is important to consider that, in the current study, the response surface methodology was used as a statistical method, which though little used to determine nutritional requirements, presents the advantage of being able to evaluate the effects of $2 \mathrm{AA}$ simultaneously, and can also estimate their optimal levels and relationships between them. Additionally, the tabulated requirement value model is based on data from experiments that determined the requirement of one AA at a time and, as proposed by Susenbeth (2006), precise detection of the optimum Trp:Lys ratio is restricted because of the relatively large intervals between the ratios tested in the studies. In this regard, using the response surface methodology is not necessary previously set the AA ratio, since is possible find the level that provide maximum or minimum response firstly and then the ratio between them. Response surface methodology can also provide the interactions between nutrients and explain if there is a positive or negative relation between 2 independent variables.

The effect of digestible Trp:Lys ratios on the LM and BF has been little studied for starter pigs. Kendall et al. (2007) studying different digestible Trp:Lys ratios for barrows, from 90 to $125 \mathrm{~kg}$, did not find differences in the BF and Longissimus dorsi area. The authors reported that these results are difficult to understand, since in the same study performance variables were affected and, therefore, differences in the carcass traits would also be expected.

Since in pig production the goal is to improve feed efficiency and, consequently, increase lean meat production, measurement of meat deposition, either by comparison or ultrasonic method is a measurement that must be considered (since it can be measured) at any stage of production, allowing more adequate estimation of the nutritional requirements, directed toward the production purpose.

When providing a balanced diet in AA, the animal tends to use them efficiently, depositing larger amounts of protein (meat) in the body. Thus, weight gain or conversion of ingested food into meat will be a consequence of greater or lesser tissue deposition in the carcass and, therefore, the observed effects on performance can also affect the quantitative variables of the carcass.

The statistical tools used to determine nutrient requirements are extremely important. Our results, using response surface methodology, can be associated with biological aspects in the Trp and Lys metabolism, where a synergism occurs in which Lys contributes to the carbon supply for the production of $\alpha$-Ketoadipic acid, and enables the use of Trp for other degradation pathways, especially the route of niacin production. This shows that the metabolism of these AA is interdependent, justifying our results, because there were no adjusted response surface models showing quadratic effects of Lys or Trp associated with the interaction between these AA.

There is no effect of SID Trp on PUN. The amount of PUN is considered a good predictor of metabolic excretion of AA, because its excess in the diet is catabolized, increasing PUN and, therefore, the urea excretion (Petersen, 2011). On the other hand, PUN reduction means that maximum AA utilization has occurred (Coma et al., 1995). The linear reduction of PUN, in our study, contributes to the understanding that the lack of one AA might limit the utilization of other AA, and that excessive AA may be deaminated. It 
is interesting that results for PUN are different from performance traits, which suggest that pigs used efficiently the AA in the diets.

Summarizing even the requirements estimated in our study are greatest than that observed in others studies (Zangeronimo, 2006; Rostagno et al., 2011), the ratios between SID Trp and SID Lys looks almost similar to that observed in others researches using different statistical procedures (Kendall et al., 2008; Susenbeth, 2006). In this way it is important to consider these results, once classical approaches can be used to determine SID Trp and SID Lys requirements, because was just observed an increase in the requirements with no greater differences on SID Trp and SID Lys ratio.

However, there are many factors that affect the ideal ratio between AA and further researches are required to assess the responses of pigs to essential AA that are studied simultaneously, because there are interactions and/or antagonisms that may occur, for example, between Trp and neutral AA. When measured simultaneously, the requirements and optimal ratio between these AA can be changed and, therefore, diets with values closest to the animal requirements could possibly be formulated.

\section{Conclusions}

We conclude for the pigs used in our study (between 15 and $30 \mathrm{~kg}$ live weight) the SID Trp and SID Lys requirements are 2.10 $\mathrm{g} / \mathrm{kg}(0.210 \%$ of diet and $0.65 \mathrm{~g} / \mathrm{Mcal} \mathrm{ME})$ and $11.98 \mathrm{~g} / \mathrm{kg}(1.198 \%$ of the diet and $3.71 \mathrm{~g} / \mathrm{Mcal}$ of ME), respectively. The corresponding Trp:Lys ratio are 17.5:100.

\section{Conflict of interest}

There is no conflict of interest.

\section{Acknowledgments}

The authors acknowledge the Conselho Nacional de Desenvolvimento Científico e Tecnológico (Brasília, Brazil) for the fellowship award, the Coordenação de Aperfeiçoamento de Pessoal de Nível Superior (Brasília, Brazil) for the scholarship, and the Evonik company (Brazil and Germany) for supplying the ingredients and performing the necessary tests for the present study.

\section{References}

Apolônio, L.R., Donzele, J.L., Oliveira, R.F.M., Silva, F.C.O., Souza, A.V.C., Lopes, D.C., Freitas, L.S., 2002. Digestibilidade ileal de aminoácidos de alimentos utilizados em dietas pré-iniciais. R. Braz. Zootec. 31, 1983-1992.

AOAC Int., 2012. Official Methods of Analysis of AOAC Int., 19th ed. Assoc. Off. Anal. Chem. Int., Gaithersburg, MD.

Baker, D.H., Chung, T.K., 1992. Ideal protein for swine and poultry, BioKyowa Technical Review 4. Nutri-Quest, Inc.

Cai, Y., Zimmerman, D.R., Ewan, R.C., 1994. Diurnal variation in concentrations of plasma urea nitrogen and amino acids in pigs given free access to feed or fed twice daily. J. Nutr. 124, 1088-1093.

Coma, J., Carrion, D., Zimmerman, D.R., 1995. Use of plasma urea nitrogen as a rapid response criterion to determine the lysine requirement of pigs. J. Anim. Sci. 73, $472-481$.

Commission Directive, 1998. Establishing community methods of analysis for the determination of amino acids, crude oils and fats, and olaquindox in feedingstuffs and amending Directive 71/393/EEC. Annex part A. Determination of amino acids. Off. J. Eur. Union L 257, 16-28.

Commission Directive, 2000. Establishing community methods of analysis for the determination of vitamin A, vitamin E and tryptophan in feedingstuffs. Annex part C. Determination of tryptophan. Off. J. Eur. Union L 174, 32-50.

Haese, D., Donzele, J.L., Oliveira, R.F.M., Abreu, M.L.T., Silva, F.C.O., Saraiva, A., 2006. Níveis de triptofano digestível em rações para suínos machos castrados de alto potencial genético para deposição de carne na carcaça dos 60 aos $95 \mathrm{~kg}$. R. Braz. Zootec 35, 2309-2313.

Henry, Y., Sève, B., Colléaux, Y., Ganier, P., Saligaut, C., Jégo, P., 1992. Interactive effects of dietary levels of tryptophan and protein on voluntary feed intake and growth performance in pigs, in relation to plasma free amino acids and hypothalamic serotonin. J. Anim. Sci. 70, 1873-1887.

Jansman, A.J.M., Le Floc'h, N., Melchior, N., Melchior, D., 2007. Tryptophan: a key nutrient in pig diets. Feed Mix 15, 1-4.

Kendall, D.C., Gaines, A.M., Allee, G.L., Usry, J.L., 2008. Commercial validation of the true ileal digestible lysine requirement for eleven- to twenty-seven-kilogram pigs. J. Anim. Sci. 86, 324-332.

Kendall, D.C., Gaines, A.M., Kerr, B.J., Allee, G.L., 2007. True ileal digestible tryptophan to lysine ratios in ninety- to one hundred twenty-five-kilogram barrows. J. Anim. Sci. 85, 3004-3012.

Kimura, F.T., Miller, V.L., 1957. Improved determination of chromic oxide in cow feed and feces. J. Agric. Food Chem. 5 216-216.

Lazzeri, D.B. 2011. Níveis de isoleucina digestíveis para suínos machos castrados dos 15 aos 30 kg MS Thesis, Universidade Estadual do Oeste do Paraná, Marechal Cândido Rondon, Paraná, Brazil.

Le Floc'h, N., Seve, B., 2007. Biological roles of tryptophan and its metabolism: potential implications for pig feeding. Livest. Sci. 112, 23-32.

Liu, H.W., Shi, B.M., Liu, D.S., Shan, A.S., 2013. Supplemental dietary tryptophan modifies behavior, concentrations of salivary cortisol, plasma epinephrine, norepinephrine and hypothalamic 5-hydroxytryptamine in weaning piglets. Livest. Sci. 151, 213-218.

Llames, C.R., Fontaine, J., 1994. Determination of amino acids in feeds: collaborative study. J.-Assoc. Off. Anal. Chem. 77, 1362-1402.

Moughan, P.J., Schuttert, G., 1991. Composition of nitrogen-containing fractions in digesta from the distal ileum of pigs fed a protein-free diet. J. Nutr. 121, 1570-1574.

Naatjes, M., Htoo, J.K., Walter, K., Tölle, K.H., Susenbeth, A., 2014. Effect of dietary tryptophan to lysine ratio on growth of young pigs fed wheat-barley or corn based diets. Livest. Sci. 163, 102-109.

NRC Nutrient Requirements of Swine. 11 th rev. ed. Natl. Acad. Sci., Washington, DC 2012.

Nemechek, J.E., Gaines, A.M., Tokach, M.D., Allee, G.L., Goodband, R.D., DeRouchey, J. M., Nelssen, J.L., Usry, J.L., Gourley, G., Dritz, S.S., 2012. Evaluation of standardized ileal digestible lysine requirement of nursery pigs from seven to fourteen kilograms. J. Anim. Sci. 90, 4380-4390.

Newman, D.J., Price, C.P., 1999. Renal function and nitrogen metabolites. In: Burtis C.A., Ashwood, E.R. (Eds.), Textbook of Clinical Chemistry. W.B. Sauders Company, Philadelphia, PA, pp. 1204-1270.

Nørgaard, J.V., Pedersen, T.F., Soumeh, E.A., Blaabjerg, K., Canibe, N., Jensen, B.B., Poulsen, H.D., 2015. Optimum standardized ileal digestible tryptophan to lysine ratio for pigs weighing 7-14 kg. Livest. Sci. 175, 90-95.

Petersen, G.I., 2011. Estimation of the ideal standardized ileal digestible tryptophan: lysine ratio in 10 to 20 pigs. (Ph.D. diss).. Univ. of Illinois, Urbana, IL.

Pozza, P.C., Gomes, P.C., Rostagno, H.S., Lopes, J., 2003. Avaliação da Perda Endógena de Aminoácidos, em Função de Diferentes Níveis de. Fibra. R. Braz. Zootec 32 1354-1361.

Quant, A.D., Lindemann, M.D., Kerr, B.J., Payne, R.L., Cromwell, G.L., 2012. Standardized ileal digestible tryptophan-to-lysine ratios in growing pigs fed cornbased and non-corn-based diets. J. Anim. Sci. 90, 1270-1279.

Rosenfelder, P., Mosenthin, R., Spindler, H.K., Jørgensen, H., Bach Knudsen, K.E., Sauer, N. Htoo, J.K., Eklund, M., 2015. Standardized ileal digestibility of amino acids in eight genotypes of soft winter wheat fed to growing pigs. J. Anim. Sci. 93, 1133-1144.

Rostagno, H.S., Albino, L.F.T., Donzele, J.L., Gomes, P.C., Oliveira, R.F., Lopes, D.C., Ferreira, A.S., Barreto, S.L.T., Euclides, R. 2011. Tabelas Brasileiras para Aves e Suínos. Composição de Alimentos e Exigências Nutricionais. Universidade Federal de Viçosa Viçosa, Minas Gerais, Brazil.

Simongiovanni, A., Corrent, E., Primot, Y., 2009. SID Trp:Lys Requirement for Piglets Determined by Meta-Analysis. Ajynomoto Eurolysine S.A.S. Technic Bulletin, 34

Stein, H.H., Kim, S.W., Nielsen, T.T., Easter, R.A., 2001. Standardized ileal protein and amino acid digestibility by growing pigs and sows. J. Anim. Sci. 79, 2113-2122.

Susenbeth, A., 2006. Optimum tryptophan:lysine ratio in diets for growing pigs: analysis of literature data. Livest. Sci. 101, 32-45.

Yin, Y.L., Li, T.J., Huang, R.L., Liu, Z.Q., Kong, X.F., Chu, W.Y., Tan, B.E., Deng, D., Kang, P., Yin, F.G., 2008. Evaluating standardized ileal digestibility of amino acids in growing pigs. Anim. Feed Sci. Technol. 140, 385-401.

Zangeronimo, M.G., 2006. Níveis de lisina digestível em rações para leitões de 9 a 25 kg. (Ph. D. diss).. Universidade Federal de Lavras, Lavras, Minas Gerais, Brazil.

Zhang, G.J., Song, Q.L., Xie, C.Y., Chu, L.C., Thacker, P.A., Htoo, J.K., Qiao, S.Y., 2012. Estimation of the ideal standardized ileal digestible tryptophan to lysine ratio for growing pigs fed low crude protein diets supplemented with crystalline amino acids. Livest. Sci. 149, 260-266.

Zhang, H., Yin, J., Li, D., Zhou, X., Li, X., 2007. Tryptophan enhances ghrelin expression and secretion associated with increased food intake and weight gain in weanling pigs. Domest. Anim. Endocrinol. 33, 47-61. 